\title{
ICT SECTOR IN REGIONS OF THE CZECH REPUBLIC IN YEARS 1995 - 2012
}

\author{
[ICT sektor v regionech České republiky v letech 1995 - 2012]
}

\author{
Kamila Turečková ${ }^{1}$ \\ ${ }^{1}$ Silesian University in Opava, School of Business Administration in Karviné, Univerzitní nám. 1934/3, \\ 73340 Karviná, Czech Republic \\ Email:tureckova@opf.slu.cz
}

\begin{abstract}
This article is focusing on analysis of sector of information and communication technology in the Czech Republic between years 1995 and 2012. Branch of information and communication technology is one of the most important economic activities because of potential for further growth of output performance and productivity. In this short study development of information and communication sector during the selected 18 years in aggregate economic levels is described through performance measured by gross value added, sectoral employment and also sectoral productivity. Emphasis is placed on developing information and communication technologies in selected 14 regions of the Czech Republic. The main aim is to find the regions which are concentrated economic activities related to information and communication technology in and to evaluate their success in interregional comparisons. It was found out that the overwhelming majority of economic activities associated with information and communication technology is concentrated in four - five regions of the Czech Republic and the regional disparities in the area of this economic branch have tendency to deepen.
\end{abstract}

Keywords: sector of information and communication technology, sectoral economic performance, sectoral labour productivity, region.

JEL classification: J20, L86, O14, R12

Doručeno redakci: 14.7.2014; Recenzováno: 21.7.2014; 1.8.2014; Schváleno k publikování: 11.2.2015

\section{Introduction}

The sector of information and communication technology (ICT) is recently one of the most potential branches of economic activities. ICT sector generates weighty gross value added which is an important source of economic development and ICT production contribute to stable qualitative economic growth of all economies at present and also in the future. ICT sector is characterized by multiplier economic effects when the activities and operations in this sector directly or indirectly affect performance in other sectors, contribute to significant savings and productivity growth, to increase of intellectual capital, especially human capital, growth of social value created by the synergy of knowledge, information and technology that are being created in this economic sector, developed and supported. All of these aforementioned positive effects associated with the activities of companies in the ICT sector, improve the competitiveness of the regions in which they operate and contribute to improving in quality of life and growth of standard of living.

The aim of this present paper is to analyse ICT sector in the Czech Republic between the years 1995 and 2012 with respect to evolution of employment in ICT sector and ICT sectoral productivity. This intention will be a supplement to particularly analysed development of ICT sector in the regions of the Czech Republic. The objective of interregional comparison of progress in ICT branch will be to find and specify the concrete regions oriented on ICT and its contribution to regional economic growth. ICT sector is determined through Section J, Information and communication, European standard classification of economic activities NACE Rev. 2.. The regions are defined by territorial level NUTS3. The empirical 
calculation and ICT sectoral and regional analysis in this paper are based on data from Czech Statistical Office, concretely from the Database of Regional Accounts - Selected Indicators by Industry. Sectoral output is measured in Gross Value Added recalculated to the prices of 2005. The covered period includes years 1995-2012. The software used was MS Excel. All calculations and graphical analysis is author's own.

The article is organized as follows. Section 1 lists and introduces ICT sector and theoretical approaches to ICT performance in aggregate and regions' level. In section 3 development of ICT sector in the whole Czech Republic during 18 years is described while in section 4 the branch of ICT in particular regions of Czech Republic with putting emphasis on interregional disparities in context of ICT performance is described. Finally, the conclusion highlights some major conclusions of development ICT economic activities in the Czech Republic and selected regions.

\section{Sector of information and communication technology}

The ICT sector is defined according to the OECD definition, ICT sector is recognized as a combination of manufacturing and services industries that capture, transmit and display data and information electronically. Moreover, the ICT sector includes industries which principal activity is to distribute ICT goods. The ICT sector could be divided into three main groups: ICT manufacturing industries, ICT trade industries and ICT services industries. In the case of the Czech Republic, the ICT sector was defined according to the Statistical Classification of Economic Activities in the European Community NACE. (Czech Statistical Office, 2014)

ICT and its application is a relevant factor of competitiveness in most of developed countries. These countries with high level of general competitiveness ground their competitiveness on considerably developing ICT services and ICT applications which, directly or indirectly, transform into remaining economic sectors (Doucek, Nedomová, 2011). There were demonstrated positive relations between ICT sector and macroeconomic (aggregate) competitiveness level of the country (see for example Jorgenson, 2001 or Venturini, 2008).

A vibrant private sector-where firms invest, create jobs, and improve their productivity promotes growth and increases opportunities for all people. There is a growing consensus in the development community that in order to improve the investment climate in their countries, governments should place a high level of priority on improving access to information and communication technology (ICT) as well as its quality. A good communication and information infrastructure is an essential part of overall infrastructure; it can improve the connectivity between firms, suppliers, and clients as well as provide business opportunities, especially for companies that are physically distant from urban centres. ICT also reduces the historical advantages of long-established firms. This allows firms from developing countries greater opportunities to participate in international trade and become connected to foreign markets. (World Bank 2006, adjusted by author)

Economic activities related with ICT are major innovators of the economy as a whole as well as generate a substantial added value. Investment into ICT generate new working place particularly in the sector of services (Atkinson, Castro, 2008). ICT contributes significantly to the gross domestic product - in USA it is 5\%, in Japan 4\% and in EU 3\% (European Commission, 2010) and also there is broad evidence that over the last two decades an increase of ICT by $10 \%$ translated into higher productivity growth of $0.5 \%$ to $0.6 \%$ (OECD, 2012). As mentioned by Voříšek and Novotný (2010) the multiplier effects of ICT in other sectors contribute to productivity growth in other sectors $(50 \%$ of labour productivity growth in the 
EU countries due to the applications of ICT) and to the performance and quality of public administration and services.

ICT services with utilities and financial and insurance activities belong to the most powerful sectors of the economy in the Czech Republic (Voříšek, Novotná, 2010). In addition, looking at the comparison of the increase in value added produced in the ICT sector, we conclude that the performance of the Czech Republic in this sector is comparable to other countries in the EU. According to Czech ICT Alliance, official export alliance of CzechTrade, some of the ways how to support the competitiveness of the Czech Republic are development in ICT services with added value, development of IT solutions and also research and development of ICT products. Referring to the above mentioned it is necessary to create conditions for the development of ICT in each country or region. Just the countries and regions with high level of involvement into ICT have great chance to succeed in the competition and to increase and enhance the standard of living of its people.

\section{Information and communication technology sector in the Czech Republic}

Assessment of ICT sector in the Czech Republic is based on performance of this sector measured by Gross Value Added (GVA) expressed in prices of year 2005 in millions of CZK. ICT sector created value of $63,488 \mathrm{~m} \mathrm{CZK}$ in 1995 which was $3.01 \%$ of total GVA of all economic activities in the Czech Republic while after 18 years it was $165,587 \mathrm{~m} \mathrm{CZK}$ which was more than $5 \%$ of total GVA created throughout the Czech Republic. The percentage share of ICT sector in overall sectoral structure of the Czech economy increased by over $68 \%$ while the amount of GVA raised during 18 years by more than $160 \%$. The tendency of positive growing trend of ICT sector in the Czech Republic is shown in Figure 1.

Figure 1: Development of Gross Value Added, Employment and Productivity in ICT sector in the Czech Republic between the years 1995 - 2012

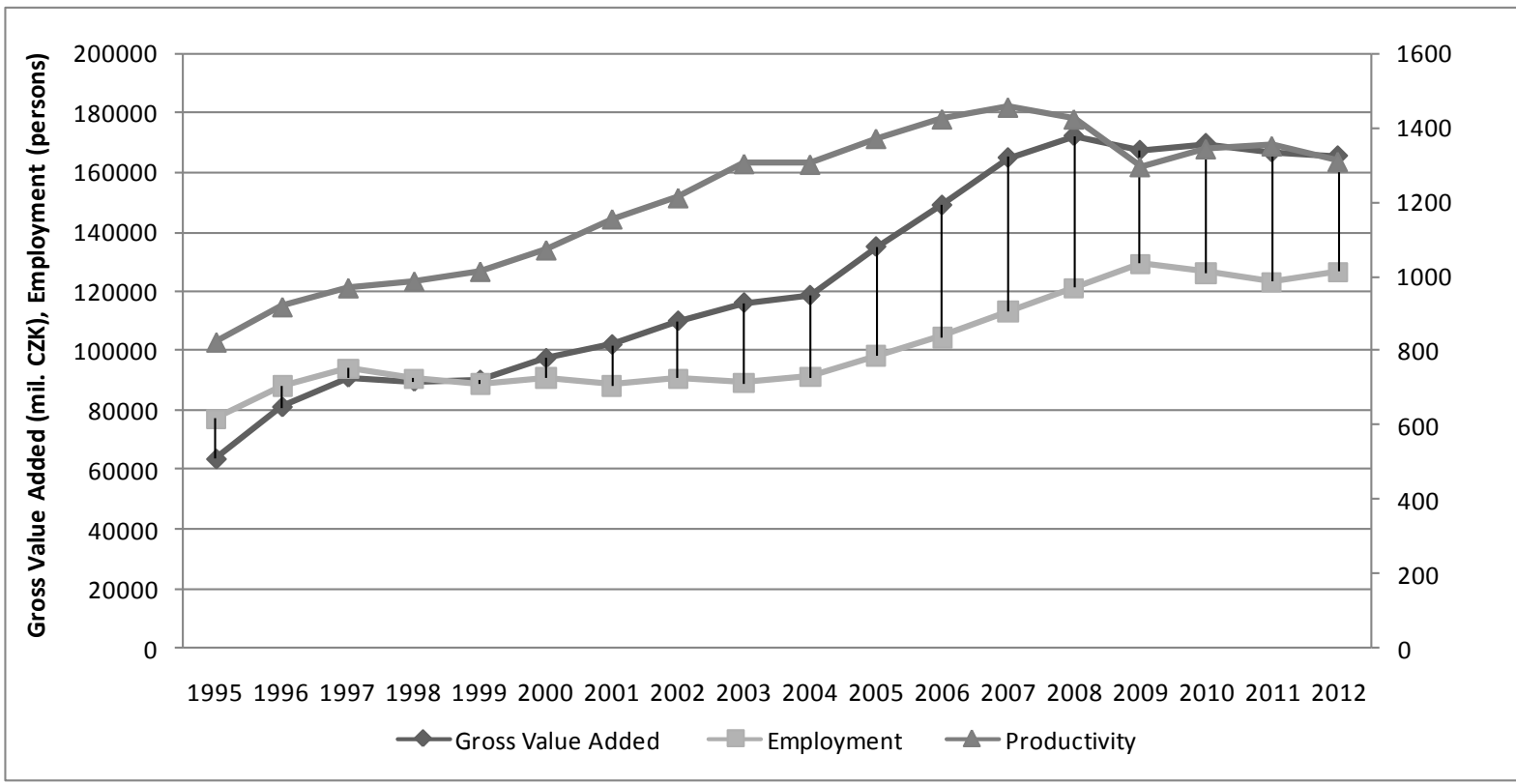

Source: Czech Statistical Office: Selected indicators by industry [online][cit. 15. June 2014]. Accessible from < http://apl.czso.cz/pll/rocenka/rocenkavyber.volba?titul=Selected\%A0indicators\%A0by\%A0industry\&my priznak=RD\&typ=1\&proc=rocenka.presB\&mylang $=\mathrm{EN} \& \mathrm{jak}=4>$, adjusted by author

It is more interesting to compare the development of amount of GVA and employment in ICT sector. How you can see in Figure 1 there was more than 77,000 people occupied in branch of ICT in 1995 while it was 126,490 persons in 2012. In intersectoral comparison the share 
in percent of employment in ICT sector on total was $1.51 \%$ and after analysed period it was $2.49 \%$ thus the sectoral employment grew by about $65 \%$. ICT labour productivity measured of the efficient use of sources to create value expressed as GVA per worker raised during 18 years by more than $59 \%$. From the beginning the productivity grew considerably but this trend slowed down and from 2007 there was decline of productivity because of economic crisis. Presently there are not any changes in productivity because of stagnation of the GVA and employment.

This short analyse of ICT sector of the Czech Republic between the years 1995 and 2012 showed the positive significant impact of branch of ICT on total economy because of rising performance expressed through gross value added and also through growing employment and sectoral productivity. It will be more interesting to analyse ICT sector in the context of development of regional labour productivity and changing in outputs of branch of ICT in a particular region in the following chapter.

\section{Information and communication technology sector in regions of the Czech Republic}

This section is focusing on interregional changes in ICT sector during the years $1995-2012$ in 14 conventional regions of the Czech Republic. The aim of the following analysis is to determine the regions in the Czech Republic, where economic activities related to ICT are concentrated. There will also be analysed development of employment in branch of ICT and sectoral labour productivity which is the significant factor for assessment of regional disparities based on ICT activities and operations.

Figure 2: Percentage share of ICT sector in selected region on total ICT sector in the Czech Republic in 1995 and 2012

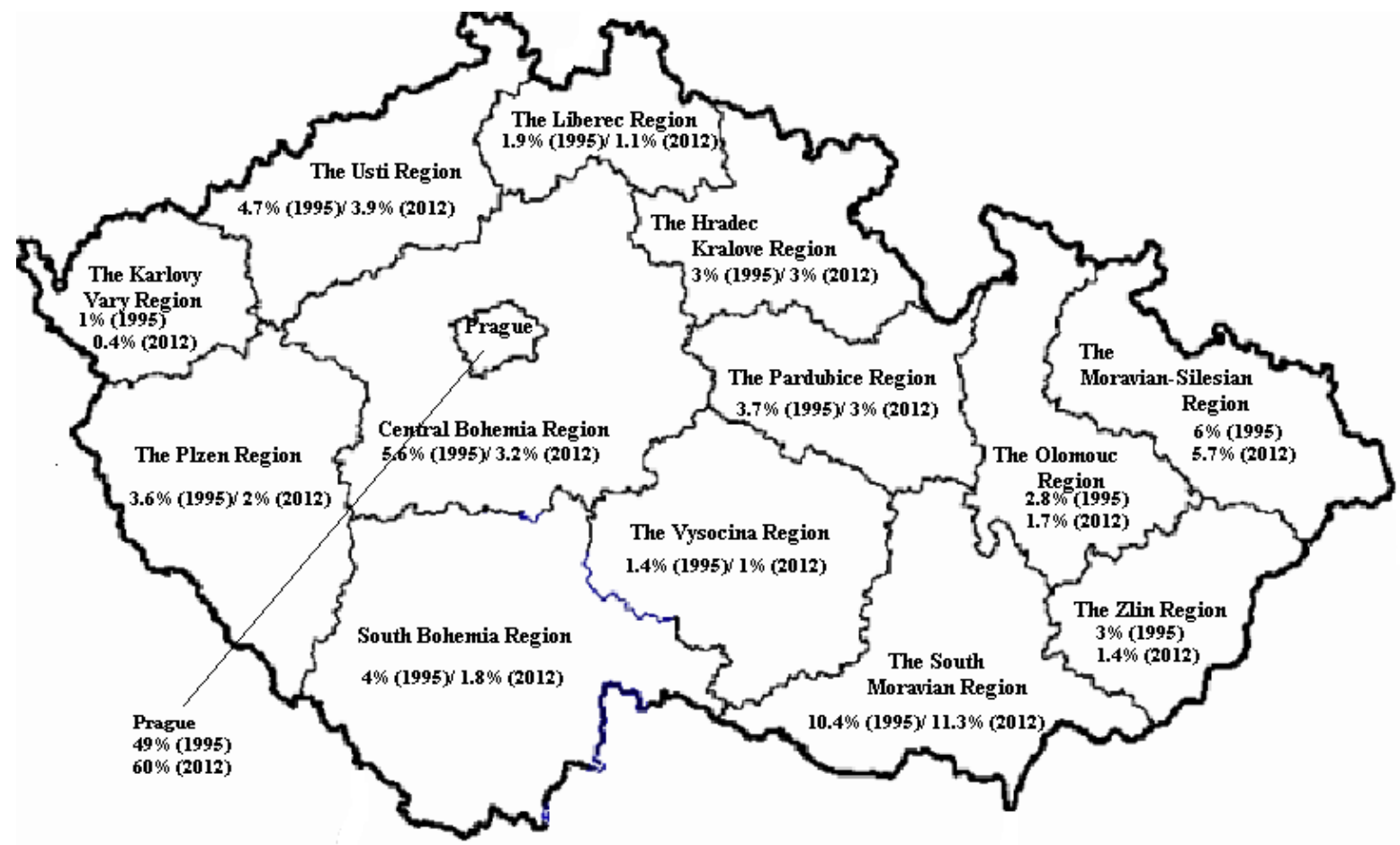

Source: Czech Statistical Office: Selected indicators by industry [online][cit. 15. June 2014]. Accessible from < http://apl.czso.cz/pll/rocenka/rocenkavyber.volba?titul=Selected\%A0indicators\%A0by\%A0industry\&my priznak=RD\&typ=1\&proc=rocenka.presB\&mylang=EN\&jak=4 >, adjusted by author 
Regional disparities in the Czech branch of ICT are considerable and they were deepened during the analysed period. If we look at Figure 2 we can see the changes in share of ICT sector in relevant regions (measured through GVA). There are only two regions - Prague and The South Moravian Region where ICT sector strengthened. In Prague from 49\% to $60 \%$ and in The South Moravian Region from $10.4 \%$ to $11.3 \%$. In The Moravian-Silesian Region, The Hradec Kralove Region and The Vysocina Region were without significant alteration, in the other the share of ICT activities decreased. In the Czech Republic three regions with dominant impact on Czech ICT have formed. It is obvious that the key region is Prague, then The South Moravian Region is followed by The Moravian-Silesian Region which is involved in sector ICT by about 6\%. As quite important in 2012 The Usti Region, Central Bohemia Region, The Hradec Kralove Region and The Pardubice Region can be considered while the rest of regions of the Czech Republic are losing their position in ICT activities.

Table 1: Employment in ICT sector in regions of the Czech Republic in 1995 and 2012

\begin{tabular}{|c|c|c|c|c|c|c|c|c|c|c|c|c|c|c|}
\hline 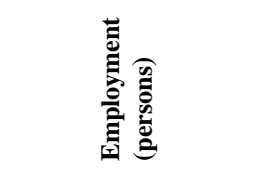 & 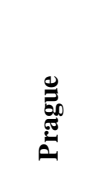 & 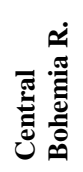 & 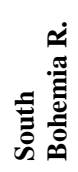 & 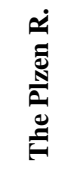 & 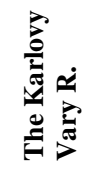 & 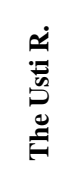 & ن & 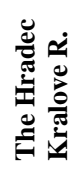 & & 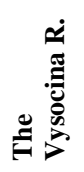 & 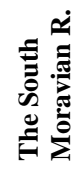 & 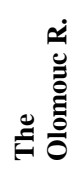 & 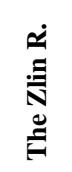 & ن \\
\hline 1995 & 38119 & 2795 & 3313 & 1858 & 586 & 2313 & 1342 & 2641 & 2371 & 1432 & 11808 & 1963 & 1966 & 4693 \\
\hline 2012 & 60221 & 8568 & 3890 & 5362 & 1181 & 2906 & 3202 & 4361 & 4139 & 2411 & 15938 & 3351 & 2362 & 8598 \\
\hline Difference (persons) & 22102 & 5773 & 577 & 3504 & 595 & 593 & 1860 & 1720 & 1768 & 979 & 4130 & 1388 & 396 & 3905 \\
\hline
\end{tabular}

Source: Czech Statistical Office: Selected indicators by industry [online][cit. 15. June 2014]. Accessible from < http://apl.czso.cz/pll/rocenka/rocenkavyber.volba?titul=Selected\%A0indicators\%A0by\%A0industry\&my priznak=RD\&typ=1\&proc=rocenka.presB\&mylang=EN\&jak=4 >, adjusted by author

Development of employment in ICT sector in regions of the Czech Republic was also unequal and did not correspond to development of regional output of ICT sector as you will see in Table 1. We can declare that the employment in ICT sector in all regions increased how it is shown in Table 1. The highest increase in the number of workers in the ICT sector in the years 1995 - 2012 was in Prague (+22,102 persons), Central Bohemia Region (+5,773), The South Moravian Region $(+4,130)$, The Moravian-Silesian Region $(+3,905)$ and in The Plzen Region $(+3,504)$. In regions with low representation or regions where there has been a reduction in the share of ICT sector as The Karlovy Vary Region, The Zlin Region, South Bohemia Region, The Usti Region or The Vysocina Region the growth of the ICT sector workers was significantly lower.

Table 2: Percentage changes in production and employment of ICT sector in regions of the Czech Republic between the years 1995 and 2012

\begin{tabular}{|c|c|c|c|c|c|c|c|c|c|c|c|c|c|c|}
\hline Percentage changes & 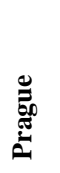 & 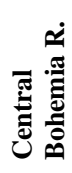 & فُ & 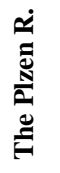 & 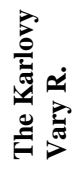 & 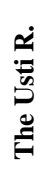 & نَّ & 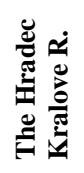 & 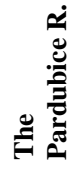 & 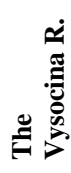 & 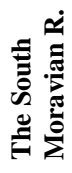 & 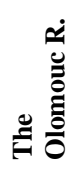 & 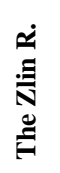 & 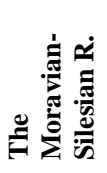 \\
\hline $\begin{array}{l}\text { Change in production } \\
\text { of ICT sector } \\
\text { Change in employment }\end{array}$ & 221 & 51 & 22 & 52 & -3 & 116 & 51 & 171 & 115 & 74 & 184 & 57 & 20 & 148 \\
\hline of ICT sector & 58 & 207 & 17 & 189 & 102 & 26 & 139 & 65 & 75 & 68 & 35 & 71 & 20 & 83 \\
\hline
\end{tabular}

Source: Czech Statistical Office: Selected indicators by industry [online][cit. 15. June 2014]. Accessible from < http://apl.czso.cz/pll/rocenka/rocenkavyber.volba?titul=Selected\%A0indicators\%A0by\%A0industry\&my priznak=RD\&typ $=1 \&$ proc=rocenka.presB\&mylang $=\mathrm{EN} \& \mathrm{jak}=4>$, adjusted by author 
In context of analysed changes in the share of ICT sector in regions in the whole Czech Republic during 18 years it is consistent to expect that the regions with high positive percentage changes in production should also have high positive affirmative changes in employment which is not true. You can see in Table 2 that on the example of Prague the production of ICT sector grew by $221 \%$ while employment grew only by $58 \%$. Similarly positive rate of change in output to a change in the number of employees have The Usti Region, The Hradec Kralove Region, The Pardubice Region, The South Moravian Regionand The Moravian-Silesian Region. What is striking is the enormous increase of employment in regions where changes in production were not so high (as The Plzen Region, The Karlovy Vary Region, The Liberec Region or Central Bohemia Region).

The same interesting percentage change is in the distribution of employees in ICT sector between years 1995 - 2012. The regions with increasing significance of ICT sector as Prague and The South Moravian Region show decreasing share of employment in ICT sector on total. Theoretically we can expect that in the regions where the percentage share of ICT on total ICT sector in the Czech Republic grows there should be more positive exchange in regional sectoral employment. We can also expect that the percentage share of sectoral employment should correspond to percentage share of sectoral productivity. For example ICT activities in Prague in 1995 accounted for $49 \%$ of all the ICT activities of Czech Republic (see Figure 2) and the percentage share of ICT employment on total was $49.4 \%$ (see Table 3 ). The best results in this comparison have Prague (1995: 49\%/49.4\%; 2012: 60\%/47.6\%), The South Moravian Region (1995: 10.4\%/15.3\%; 2012: 11.3\%/12.6\%), South Bohemia Region (1995: 4\%/4.3\%; 2012: 1.8\%/3.1\%), The Zlin Region (1995: 3\%/2.5\%; 2012: 1.4\%/1.9\%) and The Usti Region (1995: 4.7\%/3\%; 2012: 3.9\%/2.3\%). From the point of view Central Bohemia Region, The Karlovy Vary Region, The Plzen Region, The Vysocina Region and The Liberec Region did not do well. The Moravian-Silesian Region and the other three regions have not evinced any noticeable changes.

Table 3: Percentage share of employment in ICT sector on total employment in ICT sector in regions of the Czech Republic in 1995 and 2012

\begin{tabular}{|c|c|c|c|c|c|c|c|c|c|c|c|c|c|c|}
\hline 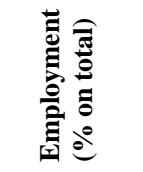 & 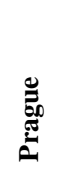 & فُ & 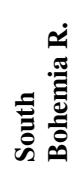 & 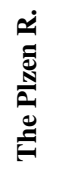 & 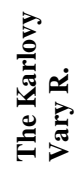 & 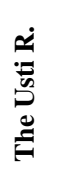 & 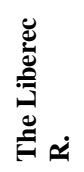 & 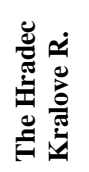 & 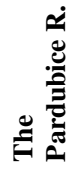 & 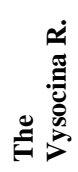 & 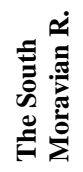 & 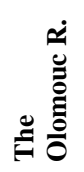 & 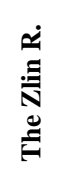 & ن \\
\hline 1995 & 49.4 & 3.6 & 4.3 & 2.4 & 0.8 & 3.0 & 1.7 & 3.4 & 3.1 & 1.9 & 15.3 & 2.5 & 2.5 & 6.1 \\
\hline 2012 & 47.6 & 6.8 & 3.1 & 4.2 & 0.9 & 2.3 & 2.5 & 3.4 & 3.3 & 1.9 & 12.6 & 2.6 & 1.9 & 6.8 \\
\hline Difference & -1.8 & 3.2 & -1.2 & 1.8 & 0.2 & -0.7 & 0.8 & 0.0 & 0.2 & 0.1 & -2.7 & 0.1 & -0.7 & 0.7 \\
\hline
\end{tabular}

Source: Czech Statistical Office: Selected indicators by industry [online][cit. 15. June 2014]. Accessible from < http://apl.czso.cz/pll/rocenka/rocenkavyber.volba?titul=Selected\%A0indicators\%A0by\%A0industry\&my priznak $=\mathrm{RD} \&$ typ $=1 \&$ proc $=$ rocenka.presB $\&$ mylang $=E N \& j a k=4>$, adjusted by author

Region's success in the creation and delivery of ICT products and services can also be assessed by comparing sectoral labour productivity. Regional sectoral labour productivity expresses gross value added created by ICT sector in particular region per employed person. Table 4 shows regions defined by NUTS3 with percentage changes of regional labour productivity in ICT sector in the Czech Republic in analyzed period. 
Table 4: Labour productivity in ICT sector (in thousands of CZK per person) in the Czech Republic during the years 1995 - 2012 and its change (in \%)

\begin{tabular}{|c|c|c|c|c|c|c|c|c|c|c|c|c|c|c|c|}
\hline 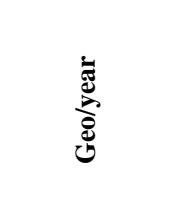 & 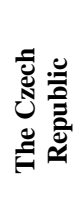 & 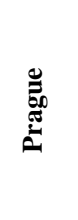 & 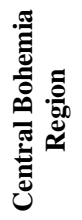 & 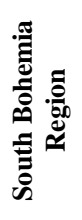 & 矛 & 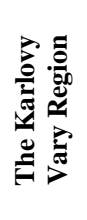 & 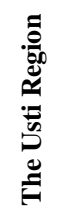 & 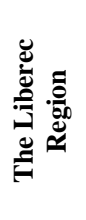 & 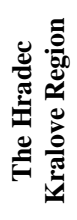 & 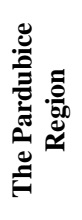 & 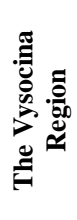 & 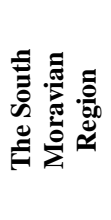 & 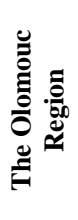 & 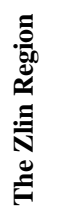 & 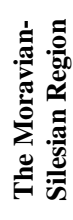 \\
\hline 1995 & 822 & 815 & 1266 & 753 & 1243 & 1044 & 1300 & 896 & 714 & 987 & 634 & 561 & 892 & 984 & 813 \\
\hline 1996 & 918 & 939 & 1365 & 873 & 1167 & 1256 & 1689 & 1050 & 707 & 958 & 608 & 646 & 899 & 644 & 926 \\
\hline 1997 & 969 & 1003 & 1442 & 950 & 1420 & 1129 & 1493 & 1096 & 658 & 889 & 495 & 669 & 1114 & 774 & 1002 \\
\hline 1998 & 986 & 1043 & 1398 & 879 & 1278 & 989 & 1444 & 1140 & 728 & 1025 & 499 & 664 & 1017 & 817 & 1015 \\
\hline 1999 & 1013 & 1127 & 1562 & 794 & 1154 & 989 & 1296 & 1132 & 665 & 838 & 719 & 643 & 985 & 789 & 1060 \\
\hline 2000 & 1071 & 1153 & 1528 & 910 & 1348 & 1053 & 1190 & 1128 & 765 & 1009 & 711 & 734 & 1238 & 761 & 1134 \\
\hline 2001 & 1154 & 1284 & 1647 & 944 & 1354 & 1149 & 1369 & 1233 & 737 & 1141 & 903 & 738 & 1043 & 792 & 1151 \\
\hline 2002 & 1211 & 1416 & 1551 & 955 & 1237 & 1399 & 1526 & 1129 & 798 & 1039 & 603 & 774 & 1068 & 792 & 1128 \\
\hline 2003 & 1303 & 1561 & 1884 & 842 & 1447 & 1343 & 1389 & 1038 & 871 & 1018 & 616 & 739 & 1169 & 781 & 1265 \\
\hline 2004 & 1302 & 1507 & 2033 & 934 & 1299 & 1553 & 1213 & 1412 & 1204 & 1021 & 590 & 759 & 1233 & 766 & 1256 \\
\hline 2005 & 1371 & 1572 & 1218 & 1078 & 1625 & 1649 & 1819 & 1879 & 963 & 1477 & 714 & 832 & 1252 & 807 & 1459 \\
\hline 2006 & 1424 & 1688 & 1388 & 982 & 1518 & 1408 & 1645 & 1252 & 891 & 1508 & 619 & 903 & 1080 & 982 & 1353 \\
\hline 2007 & 1456 & 1824 & 1310 & 785 & 1472 & 1559 & 1662 & 1269 & 756 & 1602 & 750 & 916 & 1059 & 930 & 1140 \\
\hline 2008 & 1424 & 1644 & 1537 & 839 & 1213 & 1392 & 2302 & 1350 & 1360 & 1718 & 629 & 984 & 849 & 829 & 1341 \\
\hline 2009 & 1295 & 1476 & 1304 & 733 & 1101 & 857 & 1569 & 2029 & 1402 & 1449 & 1174 & 997 & 1097 & 651 & 1008 \\
\hline 2010 & 1343 & 1592 & 821 & 998 & 1273 & 706 & 1544 & 810 & 1377 & 1828 & 1035 & 1263 & 1080 & 632 & 827 \\
\hline 2011 & 1351 & 1656 & 730 & 797 & 1099 & 670 & 1178 & 685 & 1143 & 1743 & 817 & 1339 & 1448 & 831 & 898 \\
\hline 2012 & 1309 & 1656 & 624 & 781 & 656 & 501 & 2236 & 568 & 1170 & 1217 & 657 & 1179 & 819 & 981 & 1103 \\
\hline Change (in \%) & 59,2 & 103,2 & $-50,7$ & 3,8 & $-47,2$ & $-52,0$ & 72,0 & $-36,6$ & 63,8 & 23,2 & 3,6 & 110,3 & $-8,2$ & $-0,4$ & 35,6 \\
\hline
\end{tabular}

Source: Czech Statistical Office: Selected indicators by industry [online][cit. 15. June 2014]. Accessible from < http://apl.czso.cz/pll/rocenka/rocenkavyber.volba?titul=Selected\%A0indicators\%A0by\%A0industry\&my priznak=RD\&typ=1\&proc=rocenka.presB\&mylang $=\mathrm{EN} \& \mathrm{jak}=4>$, adjusted by author

The largest increase in labour productivity in branch of ICT was in The South Moravian Region where productivity grew by $110 \%$ from approximately 561,000 CZK per working person in 1995 to $1,179,000$ CZK per employee. This region is closely followed by Prague with an increase in productivity of $103 \%$. Above average productivity growth of Czech ICT sector was also reflected in The Usti Region and The Hradec Kralove Region. Labour productivity in the ICT sector has also increased in The Pardubice Region, The Moravian-Silesian Region, The Vysocina Region and South Bohemia Region while in The Karlovy Vary Region, Central Bohemia Region, The Plzen Region, The Liberec Region, The Olomouc Region and The Zlin Region labour productivity in ICT sector decreased compared to 1995.

Changes in labour regional productivity in ICT sector are necessary to be added to the actual level of productivity in the years 1995 and 2012 because of different amounts between regions. From this point of view the highest productivity was in The Usti Region in 1995 and also in 2012. Sectoral productivity above average in branch of ICT in 2012 was also in Prague, The Hradec Kralove Region, The Pardubice Region, The South Moravian Region and The Moravian-Silesian Region. 


\section{Conclusion}

In the new global economy, information technology is the major driver of both economic growth and improved quality of life. (Atkinson, Castro, 2008) That is why we consider economic activities concerning ICT sector so important. The main aim of this paper was to compare the regions of the Czech Republic in their performance in ICT between the years 1995 and 2012. The Czech Republic as a whole had in the area of ICT activities performed well and ICT sector strengthened in analyzing years by $68 \%$ and accounted for $5 \%$ of the total sectoral structure of the Czech economy. Also aggregate ICT sectoral productivity grew by more than $59 \%$.

Table 5: Established basic criteria for evaluation ICT sector in regions for 2012

\begin{tabular}{|c|c|c|c|c|c|c|c|c|c|}
\hline Regions of Czech Republic & 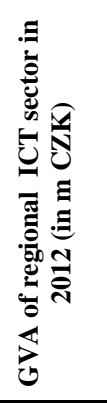 & 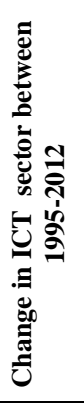 & 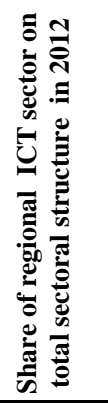 & 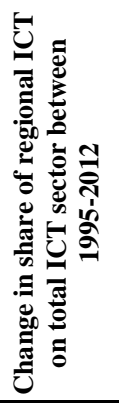 & 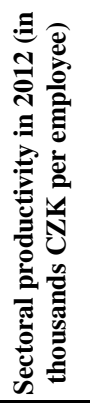 & 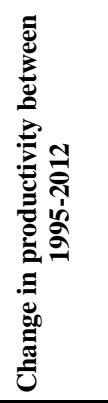 & 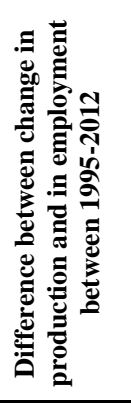 & 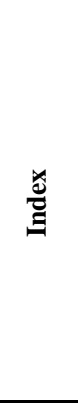 & 氖 \\
\hline Prague & 104.204 & $475 \%$ & $60.23 \%$ & $11.3 \%$ & 1.730 & $263.9 \%$ & $417 \%$ & 6676 & $\mathbf{1}$ \\
\hline Central Bohemia Region & 5.583 & $170 \%$ & $3.23 \%$ & $-2.3 \%$ & 652 & $-11.8 \%$ & $-36 \%$ & -523 & 13 \\
\hline South Bohemia Region & 3.174 & $118 \%$ & $1.83 \%$ & $-2.1 \%$ & 816 & $85.8 \%$ & $101 \%$ & 659 & 9 \\
\hline The Plzen Region & 3.675 & $173 \%$ & $2.12 \%$ & $-1.5 \%$ & 685 & $-5.5 \%$ & $-16 \%$ & -481 & 12 \\
\hline The Karlovy Vary Region & 618 & $73 \%$ & $0.36 \%$ & $-0.6 \%$ & 523 & $-14.1 \%$ & $-28 \%$ & -894 & 14 \\
\hline The Usti Region & 6.789 & $287 \%$ & $3.92 \%$ & $-0.8 \%$ & 2.336 & $207.9 \%$ & $261 \%$ & 3377 & 3 \\
\hline The Liberec Region & 1.901 & $171 \%$ & $1.10 \%$ & $-0.8 \%$ & 594 & $13.5 \%$ & $32 \%$ & -252 & 11 \\
\hline The Hradec Kralove Region & 5.329 & $384 \%$ & $3.08 \%$ & $0.1 \%$ & 1.222 & $193.4 \%$ & $319 \%$ & 3093 & 4 \\
\hline The Pardubice Region & 5.261 & $285 \%$ & $3.04 \%$ & $-0.6 \%$ & 1.271 & $120.6 \%$ & $211 \%$ & 2024 & 6 \\
\hline The Vysocina Region & 1.656 & $212 \%$ & $0.96 \%$ & $-0.5 \%$ & 687 & $85.6 \%$ & $144 \%$ & 835 & 7 \\
\hline The South Moravian Region & 19.628 & $408 \%$ & $11.34 \%$ & $0.9 \%$ & 1.232 & $276.5 \%$ & $373 \%$ & 5425 & 2 \\
\hline The Olomouc Region & 2.868 & $181 \%$ & $1.66 \%$ & $-1.1 \%$ & 856 & $64.4 \%$ & $110 \%$ & 668 & 8 \\
\hline The Zlin Region & 2.420 & $114 \%$ & $1.40 \%$ & $-1.6 \%$ & 1.025 & $78.4 \%$ & $94 \%$ & 631 & 10 \\
\hline The Moravian-Silesian Region & 9.907 & $345 \%$ & $5.73 \%$ & $-0.3 \%$ & 1.152 & $142.8 \%$ & $262 \%$ & 2908 & 5 \\
\hline
\end{tabular}

Source: Czech Statistical Office: Selected indicators by industry [online][cit. 15. June 2014]. Accessible from < http://apl.czso.cz/pll/rocenka/rocenkavyber.volba?titul=Selected\%A0indicators\%A0by\%A0industry\&my priznak=RD\&typ=1\&proc=rocenka.presB\&mylang=EN\&jak=4 >, adjusted by author

Analysis of 7 basic selected indicators characterizing ICT determined performance and success in ICT activities in regions and set the order of them as is shown in Table 5. It was used Point Method for setting up the index and after ranking. The weights in the index for the indicators were the same. Established criteria for ranking ICT were amount of gross value added (in basic price) of regional ICT sector in 2012, regional percentage change in ICT sector during analyzed period which was 1995 - 2012, percentage share of regional ICT sector on total in 2012, percentage change in share of regional ICT on total during analyzed period, regional sectoral productivity in 2012, percentage change in regional sectoral productivity during analyzed period and difference between percentage change in production and employment between years 1995 and 2012. 
On regional level in the Czech Republic great disparity has evinced branch of ICT, which deepened over 18 years. In territory of the Czech Republic 4 to 5 regions with concentrated ICT activities have emerged which Prague region is, from this point of view, the most important in, as there was produced about $60 \%$ of total Czech ICT production. In the context of what was written above and on the basis of established criteria, we can determine the ranking of regions in performance and success in ICT activities. Prague on its imaginary first place was followed by The South Moravian Region. Third of the most significant regions is The Usti Region closely followed by The Hradec Kralove and The MoravianSilesian Region. ${ }^{1}$ Region which also performed well was The Pardubice Region. In other regions (in next order: The Vysocina Region, The Olomouc Region, South Bohemia Region, The Zlín Region, The Liberec Region, The Plzen Region, Central Bohemia Region and last one The Karlovy Vary Region) ICT activities are not so important from the aggregate perspective and their contribution to the aggregate performance of ICT sector is minimal.

\section{Acknowledgement}

This research was financially supported by the Student Grant Competition SU within the project SGS/7/2012 "The influence of regional disparities on the business environment".

\section{References}

[1] ATKINSON, R. D. and D. D. CASTRO, 2008. Digital Quality of Life [online]. [cit. 2014-06-20]. Accessible from: http://www.itif.org/files/DQOL.pdf

[2] CZECH ICT ALLIANCE, 2014. Czech ICT Alliance [online]. [cit. 2014-06-21]. Accessible from: http://www.czechict.cz/

[3] CZECHINVEST, 2014. ICT [online]. [cit. 2014-06-22]. Accessible from: http://www.czech invest.org/en/ict

[4] CZECH STATISTICAL OFFICE, 2014. ICT sector [online]. [cit. 2014-06-20]. Accessible from: http://www.czso.cz/eng/redakce.nsf/i/ict_sector

[5] CZECH STATISTICAL OFFICE, 2014. Selected indicators by industry [online]. [cit. 2014-06-25]. Accessible from: http://apl.czso.cz/pll/rocenka/rocenkavyber.volba?titul= Selected\%A0indicators\%A0by\%A0industry\&mypriznak=RD\&typ=1\&proc=rocenka.pre sB\&mylang=EN\&jak=4 >

[6] DOUCEK, P. and L. NEDOMOVÁ, 2011. Porovnání ICT sektorů v České republice a Slovenské republice. AOP, 19(5), 68-86. ISSN 0572-3043.

[7] EUROPEAN COMMISSION, 2010. Europe's Digital Competitiveness Report 2010 [online]. [cit. 2014-06-15]. Accessible from: http://ec.europa.eu/information_society/ newsroom/cf/item detail.cfm?item_id=6499

[8] JORGENSON, D. W., 2001. Information Technology and the U.S. Economy [online]. [cit. 2014-08-30]. Accessible from: http://scholar.harvard.edu/files/jorgenson/files/ itanduseconomy_americaneconomicreview.pdf

\footnotetext{
${ }^{1}$ Thanks to investments in infrastructure other Czech regions than Prague are gaining attractiveness, especially in the ICT sector. Brno, the second largest city in the Czech Republic, is considered to be the Czech IT hub, where companies' needs are fulfilled by qualified professionals, R\&D facilities and institutions, and advanced ICT infrastructure. Ostrava has been gaining importance in recent years and is on the path to greater international recognition thanks to projects such as IT4Innovations. It is thus not surprising that companies such as Tieto have decided to establish their centre there. (CzechInvest, 2014)
} 
[9] JORGENSON, D. W. and K. J. STIROH, 1999. Information Technology and Growth [online]. [cit. 2014-08-30]. Accessible from: http://www.tos.camcom.it/Portals/_ UTC/Studi/ScenariEconomici/39746563588947974/techgrowth.pdf

[10] JORGENSON, D. W. and K. VU, 2005. Information technology and the world economy [online]. [cit. 2014-08-30]. Accessible from: http://www.frbsf.org/economicresearch/files/6_ITAndWorldEconomy.pdf

[11] KUTSCHERAUER, A. a kol., 2010. Regionální disparity v územním rozvoji České republiky, jejich vznik, identifikace a eliminace [online]. [cit. 2014-05-22]. Accessible from: http://disparity.idealnihosting.cz/vysledky/15_zaverecna_\%20zprava_2010.pdf

[12] THE WORLD BANK, 2006. Information and communication for development [online]. [cit. 2014-08-30]. Accessible from: http://web.worldbank.org/WBSITE/ EXTERNAL/TOPICS/EXTINFORMATIONANDCOMMUNICATIONANDTECHNO LOGIES/0,,contentMDK:20831214 pagePK:210058 piPK:210062 theSitePK:282823,0 $0 . h t m l$

[13] VENTURINI, F., 2008. Information Technology, Research \& Development, or Both? What Really Drives A Nation's Productivity [online]. [cit. 2014-05-30]. Accessible from: http://www.dea.univpm.it/quaderni/pdf/321.pdf

[14] VOŘÍŠEK, J., O. NOVOTNÝ a kol., 2010. Studie: ICT a konkurenceschopnost České republiky [online]. [cit. 2014-06-10]. Accessible from: http://www.cssi.cz/cssi/studie-ictkonkurenceschopnost 


\section{Appendix - Data sources}

Table A.1: Gross value added by sector of information and communication technology between years 1995 - 2012 (in million of CZK, and in prices of year 2005)

\begin{tabular}{|c|c|c|c|c|c|c|c|c|c|c|c|c|c|c|c|}
\hline Geo/years & $\begin{array}{l}\text { The Czech } \\
\text { Republic }\end{array}$ & Prague & $\begin{array}{c}\text { Central } \\
\text { Bohemia } \\
\text { Region }\end{array}$ & $\begin{array}{c}\text { South } \\
\text { Bohemia } \\
\text { Region }\end{array}$ & $\begin{array}{l}\text { The } \\
\text { Plzen } \\
\text { Region }\end{array}$ & $\begin{array}{c}\text { The } \\
\text { Karlovy } \\
\text { Vary } \\
\text { Region } \\
\end{array}$ & $\begin{array}{l}\text { The Usti } \\
\text { Region }\end{array}$ & $\begin{array}{l}\text { The } \\
\text { Liberec } \\
\text { Region }\end{array}$ & $\begin{array}{c}\text { The } \\
\text { Hradec } \\
\text { Kralove } \\
\text { Region } \\
\end{array}$ & $\begin{array}{c}\text { The } \\
\text { Pardubice } \\
\text { Region }\end{array}$ & $\begin{array}{l}\text { The } \\
\text { Vysocina } \\
\text { Region }\end{array}$ & $\begin{array}{c}\text { The } \\
\text { South } \\
\text { Moravian } \\
\text { Region } \\
\end{array}$ & $\begin{array}{c}\text { The } \\
\text { Olomouc } \\
\text { Region }\end{array}$ & $\begin{array}{l}\text { The } \\
\text { Zlin } \\
\text { Region }\end{array}$ & $\begin{array}{c}\text { The } \\
\text { Moravian- } \\
\text { Silesian } \\
\text { Region } \\
\end{array}$ \\
\hline 1995 & 63488,00 & 31067,06 & 3538,92 & 2493,52 & 2310,15 & 611,81 & 3007,65 & 1203,06 & 1885,14 & 2341,00 & 908,29 & 6618,55 & 1751,46 & 1934,84 & 3816,55 \\
\hline 1996 & 81027,00 & 41260,36 & 4399,33 & 3057,11 & 2761,70 & 860,47 & 4385,69 & 1524,01 & 2270,86 & 2717,77 & 1083,17 & 8097,25 & 2192,09 & 1651,26 & 4765,94 \\
\hline 1997 & 91005,00 & 48067,56 & 5090,44 & 3410,82 & 3479,59 & 833,20 & 3835,35 & 1621,43 & 2690,04 & 2820,97 & 1019,67 & 7978,86 & 2758,81 & 1899,16 & 5499,10 \\
\hline 1998 & 89640,00 & 48337,89 & 4993,09 & 3165,62 & 3113,92 & 734,60 & 3715,06 & 1525,70 & 2504,36 & 2861,44 & 1033,97 & 7971,15 & 2607,76 & 1883,98 & 5191,47 \\
\hline 2000 & 97415,00 & 53881,64 & 5408,60 & 3395,13 & 3227,89 & 715,97 & 3467,28 & 1545,63 & 2715,23 & 3160,12 & 1302,96 & 8482,37 & 2627,79 & 1892,14 & 5592,24 \\
\hline 2001 & 102046,00 & 57439,14 & 5853,93 & 3545,03 & 3469,15 & 700,79 & 3502,88 & 1517,49 & 2697,76 & 3073,97 & 1669,24 & 8443,15 & 2537,58 & 1790,43 & 5805,46 \\
\hline 2002 & 110024,00 & 63061,54 & 6419,48 & 3762,09 & 3354,82 & 818,60 & 3820,12 & 1634,14 & 2902,76 & 3080,94 & 1384,69 & 8988,28 & 2856,95 & 1971,15 & 5968,43 \\
\hline 2003 & 116166,00 & 69885,29 & 7266,66 & 3399,96 & 3259,13 & 785,61 & 3605,17 & 1422,35 & 3144,46 & 2857,78 & 1179,93 & 8732,27 & 2807,48 & 1879,03 & 5940,88 \\
\hline 2004 & 118644,00 & 69718,20 & 8144,22 & 3533,16 & 3194,03 & 921,22 & 3117,67 & 1726,42 & 3949,64 & 3016,52 & 1366,46 & 9229,06 & 2809,27 & 1896,98 & 6021,15 \\
\hline 2005 & 135006,00 & 78595,42 & 4950,96 & 4154,97 & 4631,97 & 1033,99 & 5255,96 & 2319,98 & 3080,98 & 4490,97 & 1598,99 & 11208,92 & 3482,97 & 2146,98 & 8052,94 \\
\hline 2006 & 148994,00 & 91275,67 & 6075,56 & 4272,94 & 4899,17 & 884,02 & 5115,48 & 1959,67 & 3118,28 & 4878,43 & 1611,98 & 11916,04 & 2950,37 & 2255,99 & 7780,39 \\
\hline 2008 & 172298,00 & 102186,98 & 7788,28 & 4592,84 & 3936,44 & 845,05 & 7298,17 & 2014,90 & 5469,98 & 5818,11 & 1834,02 & 15832,31 & 2928,02 & 2544,88 & 9208,04 \\
\hline 2009 & 167434,00 & 97289,66 & 7009,78 & 3884,82 & 4116,58 & 808,31 & 7167,45 & 2044,99 & 5250,69 & 5962,11 & 1994,65 & 16568,92 & 3326,32 & 2440,13 & 9569,58 \\
\hline 2010 & 169763,00 & 100731,58 & 6000,49 & 3607,89 & 4173,15 & 757,25 & 7063,75 & 1965,73 & 5403,07 & 5710,06 & 1761,07 & 17301,71 & 3294,08 & 2214,24 & 9778,93 \\
\hline 2011 & 166779,00 & 100819,54 & 5551,01 & 3334,67 & 3720,04 & 624,52 & 6532,82 & 2041,08 & 5147,24 & 5400,93 & 1664,43 & 17294,00 & 2706,27 & 2124,35 & 9818,10 \\
\hline 2012 & 165587,00 & 99731,39 & 5343,37 & 3037,77 & 3517,26 & 591,47 & 6497,61 & 1819,41 & 5100,27 & 5035,19 & 1584,92 & 18785,53 & 2744,90 & 2316,13 & 9481,78 \\
\hline
\end{tabular}

